\title{
DIALLELE CROSS ANALYSIS FOR GRAIN YIELD AND ITS COMPONENTS IN SOME BREAD WHEAT CROSSES
}

\author{
WAFAA A. EL-AWADY AND SABAH H. ABO EL ELA \\ Field Crops Research Institute, ARC, Giza, Egypt \\ (Manuscript received 10 April 2011)
}

\begin{abstract}
A diallel cross among six bread wheat genotypes (parents) namely; Sids 1, Giza 168, Sakha94, Gemmeiza 9, Line 5 and Line 42 was carried out in 2008/2009 season to studay some genetic parameters in $F_{1}$ and $F_{2}$ generations for grain yield and its components i.e. plant height, noumber of spikes/plant, noumber of kernels/spike, 100- kernal weight and grain yield/plant. Genotypes mean squares were significant for all studied characters. Mean squares for parents vs crosses as an indication for heterosis were significant for all studied characters in the $F_{1}$ and $F_{2}$. Inbreeding depression was dectected in $F_{2}$ for grain yield in 13 crosses and rangead from 22.94 to $59.71 \%$. Similarly, inbreeding depression, for number of spikes/plant ranged from 13.41 to 39.21 in nine crosses from 21.31 to 59.33 for number of kernels/spike in ten crosses, and from 16.28 to $72.91 \%$ for kernel weight in 11 crosses. Both general and specific combining ability (GCA and SCA, respectively, ), were significant for all studied characters in $F_{1}$. These results indicate the importance of both additive and dominance genetic effects in the inheritance of most studied characters. However, the additive gene action (GCA) was of great importance in the performance of most studied characters. Moreover, Results indicated that the cultivar (Giza 168) was good combiner for all studied characters while (line 5) was best combiner for plant height, number of spikes/plant and kernel weight. Moreover, the crosses $\left(\mathrm{P}_{2} \times \mathrm{P}_{5}\right),\left(\mathrm{P}_{4} \times \mathrm{P}_{5}\right)$ and $\left(\mathrm{P}_{3} \times \mathrm{P}_{6}\right)$ are considered promising for grain yield improvement as they showed high specific combining ability effects.
\end{abstract}

\section{INTRODUCTION}

Wheat, is the leading human food crop in Egypt. The total national consumption is about 14 million tons whereas, the national wheat production was fluctuating from seven to eight million tons during the last five years. Therfore, Egypt imports about six million tons yearly. Reducing the gap between national wheat production and consumption is a national goal. For doing so, breeding for new high yielding cultivars is an ongoing process for the wheat breeders. The assessment of the nature of genetic variation is crucial to any breeding program, since the choice of an appropriate breeding method depends on the relative importance of various genetic parameters. In wheat, plant height and spike characters are important attributes that determine the desirability of progeny of any cross. The appropriate 
selection of these characters may greatly contribute towards enhancement in the yielding ability. Thus, information on the nature of gene action with respect to these character would be useful in the development of better cultivars. Dominance gene action would tend to favor the production of hybrids, whereas additive gene action signifies that standard selection procedures would be more effective in breeding about advantageous changes in the characters (Edwards et. al., 1976).

Successful breeding programs need continuous information on the genetic variation and systems governing grain yield and its components. Contradictory results were obtained by several authors with respect to genetic systems governing wheat grain yield and its components. For instance, Uddin and Joarder (1987), Hendawy (1990) and Ikram and Tanah (1991) indicated that, additive and non-additive gene effects played equal roles in the inheritance of grain yield, number of spikes/plant, number of kernels/spike and kernel weight. Morover, El-Hennawy (1992) revealed that additive and dominance gene effects were important for grain yield and number of kernels/spike. Furthermore the results obtained by Mohammed (1999) from eight wheat genotypes revealed that, additive and non-additive gene effects were controlling the genetic systems of grain yield and its components. In addition, ElSayed et. al. (2000) and Mostafa (2002) found that both additive and dominance variances were significant for number of spikes/plant, number of kernels/spike, kernel weight and grain yield/plant. Similarly, Hamada and Tawfelis (2001) showed that additive and non- additive gene effects had important roles in controlling the genetic system for plant height, number of spikes/plant, number of kernels/spike, kernel weight and grain yield/plant.

On the other hand, Sharma and Smith (1986) as well as Salem and Hassan (1991) found that non-additive gene effects were more important in the inheritance of grain yield/plant and number of spikes/plant. Similarly, Dawam and Hendawi (1990), and Darwish (1992) found that dominance gene effects were significant for grain yield/plant, number of kernels/spike and kernel weight. Reversely to that, Mekhamer (1995) reported that additive gene effects were significant for number of kernels/spike and kernel weight. On the other side, El-Sayesd et. al. (2000), Ashoush et al (2001) and Abd El-Hameed (2002), found that GCA and SCA were significant for days to heading, maturity, plant height, number of spikletes/spike and flag leaf area.

The main objectives of this investigation were to study the effect of general and specific combining ability, and inbreeding depression in a six parental diallel cross of bread wheat . 


\section{MATERIALS AND METHODS}

This study was conducted at Bahteem Agricultural Research Station, Agricultural Research Center (ARC), during the three successive growing seasons $2007 / 2008$, to $2009 / 2010$. Four bread wheat cultivars and two promising lines representing a wide range of genetic variability were selected for this study, however, names and pedigrees of these genotypes presented in Table 1.

Table 1. Names and Pedigrees of Six Parents of Bread Wheat .

\begin{tabular}{|c|l|l|c|}
\hline No. & \multicolumn{1}{|c|}{ Name } & \multicolumn{1}{|c|}{ Cross and Pedigree } & Origin \\
\hline$P_{1}$ & Sids 1. & HD 2172/Pavon"s"/1158.571 Maya 74 "s" & Egypt \\
$P_{2}$ & Giza 168 & MRL/BUC//Seri. & Egypt \\
$P_{3}$ & Sakha 94 & Sakha 92/ TR810328 & Egypt \\
$P_{4}$ & Gemmeiza9 & ALD "S"/HAVAC "S"//CMH74A.630/SX & Egypt \\
$P_{5}$ & Lien 5. & MIANYANG 20-2CHN-0CHN-0ET. & Mexico \\
$P_{6}$ & Line 42 & 2V879. C8.11//V979/3/STAR/4/STAR & Mexico \\
& & CMSS92Y01815T-20Y-010M-010Y-9M-0Y0-0ET & \\
\hline
\end{tabular}

In $2007 / 2008$ season, all possible crosses (without reciprocals) among the six parents under study were made. In the second season, (2008/2009), the 21 entries ( $15 \mathrm{~F}_{1}$ 's and 6 parents) were planted in the field using the randomized complete block design (RCBD) with three replications according to Steel and Torri (1980). Also, some of $F_{1}$ plants were selfed to obtain $F_{2}$ seeds. In 2009/2010, season parents, $F_{1}$ and $F_{2}$ were planted in the field using RCBD with three replications. Each entry was planted in a plot of three rows; for parents and $F_{1}$ and ten rows for $F_{2}$. Every row was $3.0 \mathrm{~m}$ long and $30 \mathrm{~cm}$ apart, and contained 15 seeds spaced $20 \mathrm{~cm}$ apart . Data were recorded on a random sample of 10 guarded plants from each row. number of spikes/plant SP/PI, number of kernels/spike (No. kl/s), 100- kernel weight (k.wt), and grain yield/plant (Gy/pl).

The analysis of variance for combining ability effects was calculated according to Griffing (1956). Inbreeding depression, (the converse of heterosis that reflects deteration accompanying inbreeding through the successive generations of selfing) was calculated by the the difference between $F_{1}$ and $F_{2}$ generation means as percent of $F_{1}$ mean. 


\section{RESULTS AND DISCUSSION}

Analysis of variance for all studied characters (plant height, number of spike/plant, number of kernels/spike, kernel weight and grain yield/plant), for $F_{1}$ is presented in Table (2). Analysis indicated that the mean squares of genotypes were significant for all studied characters in the $F_{1}$ expet for kernel weight. suggesting the presence of true differences among genotypes. Mean squares due to genotyps were significant for all studied characters. Table (2) shows the results of the analysis for GCA , SCA. and the GCA/SCA ratio. The variance associated with GCA was significant in all studied characters in the $F_{1}$ except for no.spikes/plant. The same level of significance was found in most cases for SCA for all studied characters except for plant height and kernal weight, in the $F_{1}$. Thus both GCA and SCA revealed the presence of both additive and dominance types of gene effects for most characters. From Table 2, it could be noticed that GCA was relatively larger than SCA for the studied characters except for number of spikes/plant and grain yeld/plant in the $F_{1}$ The ratio of GCA/SCA suggested a predominant role for additive type of gene action for these characters and that selection in early generation could be successful.

Table 2. Mean squares from ANOVA and combining ability analysis in the F1 generation of wheat crosses .

\begin{tabular}{|c|c|c|c|c|c|c|}
\hline Source & d.f & $\begin{array}{l}\text { Plant } \\
\text { height } \\
(\mathrm{cm})\end{array}$ & $\begin{array}{l}\text { No.of } \\
\text { Spikes } \\
\text { /plant. }\end{array}$ & $\begin{array}{c}\text { No. of } \\
\text { Kerneles } \\
\text { /spikes }\end{array}$ & $\begin{array}{c}100- \\
\text { Kernels } \\
\text { Weight } \\
(\mathrm{gm})\end{array}$ & $\begin{array}{c}\text { Grain } \\
\text { yield/plant } \\
(\mathrm{gm})\end{array}$ \\
\hline $\mathbf{F}_{1}$ & & & & & & \\
\hline Genotypes & 20 & $121^{* *}$ & $57.35 * *$ & $114.67 *$ & 0.545 & $1728.55^{*}$ \\
\hline GCA & 5 & $183.58 *$ & 53.99 & 131.11* & $1.2523 *$ & 934.37* \\
\hline SCA & 15 & 101.38 & $58.47 *$ & $109.16 *$ & 0.309 & $1993.27 *$ \\
\hline Error & 40 & 4.485 & 2.14 & 5.96 & 0.104 & 41.058 \\
\hline GCA/SCA & & 1.811 & 0.923 & 1.202 & 4.074 & 0.469 \\
\hline
\end{tabular}

* Significant at $5 \% \quad$ level of probability

\section{Genotypes performancce}

The mean performance of six wheat parental genotypes in the $F_{1}$ and $F_{2}$ generations are presented in Table (3) and Table (4), respectively. It is obvious that the cultivar Giza $168\left(\mathrm{P}_{2}\right)$ ranked first for, noumber of spike/ plant and grain yield/plant. Morever, the cultivar, Sakha $94\left(P_{3}\right)$ ranked the first for number of kernels/spike while, line $5\left(P_{5}\right)$ ranked the first for kernel weight. 
The mean performance of tested crosses is presented in Table (3). The four crosses $\left(P_{2} \times P_{4}\right),\left(P_{2} \times P_{5}\right)$ and $\left(P_{3} \times P_{6}\right)$ were the highest number of spikes/plant, while the four crosses $\left(P_{1} \times P_{2}\right),\left(\left(P_{2} \times P_{4}\right),\left(P_{2} \times P_{5}\right)\right.$ and $\left(P_{3} \times P_{6}\right)$ gave the heighest number of kernels /spike. The heaviest kernel weight was obtained from the crosses $\left(\mathrm{P}_{2} \times \mathrm{P}_{4}\right)$ and $\left(\mathrm{P}_{2} \mathrm{XP}_{3}\right)$. On other hand, the highest grain yield /plant resulted from the crosses $\left(\mathrm{P}_{4} \times \mathrm{P}_{6}\right),\left(\mathrm{P}_{2} \times \mathrm{P}_{5}\right),\left(\mathrm{P}_{2} \times \mathrm{P}_{6}\right) . \mathrm{P}_{2}$ and $\mathrm{P}_{4}$ are considered good combiners and had the best yielder and surpassed all other crosses significantly. It was obvious that genes for higher yield were transmitted from $\mathrm{P}_{2}$ with a transgressive increase than that parent. In addation, Besides, $\mathrm{P}_{4}$ seems to be good combiner for grain yield based on kernel weight.

Table 3. Mean performanceof parents and F1 for the studied characters.

\begin{tabular}{|c|c|c|c|c|c|}
\hline Genotyupes & $\begin{array}{l}\text { PI- H } \\
(\mathrm{cm})\end{array}$ & $\begin{array}{l}\text { No.of } \\
\text { SP/p }\end{array}$ & $\begin{array}{c}\text { No. } \\
\text { K / SP }\end{array}$ & $\begin{array}{c}100 \\
\text { K.wt } \\
\text { (gm) }\end{array}$ & $\begin{array}{l}\text { G.Y } \\
\text { /PI. } \\
\text { (gm) }\end{array}$ \\
\hline P1 (Sids1) & 104.0 & 20.3 & 72.0 & 3.8 & 63.0 \\
\hline P2 (Giza 168) & 118.0 & 25.0 & 79.0 & 4.9 & 82.6 \\
\hline P3 (Sakha94) & 102.3 & 22.0 & 81.3 & 4.5 & 62.3 \\
\hline P4 (Gem. 9) & 107.0 & 22.3 & 74.7 & 4.3 & 41.6 \\
\hline P5 (Line5) & 110.0 & 22.0 & 65.3 & 5.4 & 45.7 \\
\hline P6 (Line42) & 107.7 & 21.3 & 64.0 & 5.1 & 53.7 \\
\hline$P_{1} \times P_{2}$ & 116.3 & 24.6 & 76.0 & 4.9 & 64.0 \\
\hline$P_{1} \times P_{3}$ & 111.0 & 24.7 & 73.3 & 4.3 & 67.3 \\
\hline $\mathrm{P}_{1} \times \mathrm{P}_{4}$ & 113.0 & 21.7 & 76.3 & 4.3 & 61.7 \\
\hline$P_{1} \times P_{5}$ & 115.0 & 22.0 & 89.7 & 4.4 & 71.3 \\
\hline$P_{1} \times P_{6}$ & 111.0 & 28.0 & 72.7 & 4.2 & 76.7 \\
\hline$P_{2} \times P_{3}$ & 115.0 & 25.7 & 75.33 & 5.1 & 62.3 \\
\hline $\mathrm{P}_{2} \times \mathrm{P}_{4}$ & 114.0 & 34.6 & 86.6 & 5.5 & 82.0 \\
\hline$P_{2} \times P_{5}$ & 125.0 & 32.0 & 81.0 & 4.9 & 119.0 \\
\hline $\mathrm{P}_{2} \times \mathrm{P}_{6}$ & 111. & 28.0 & 77.6 & 4.7 & 115.7 \\
\hline $\mathrm{P}_{3} \times \mathrm{P}_{4}$ & 124.0 & 20.0 & 72.7 & 4.5 & 79.6 \\
\hline$P_{3} \times P_{5}$ & 116.6 & 29.0 & 72.0 & 4.4 & 64.7 \\
\hline $\mathrm{P}_{3} \times \mathrm{P}_{6}$ & 99.6 & 26.3 & 80.3 & 4.9 & 123.0 \\
\hline $\mathrm{P}_{4} \times \mathrm{P}_{5}$ & 115.7 & 30.6 & 74.6 & 4.9 & 115.3 \\
\hline $\mathrm{P}_{4} \times \mathrm{P}_{6}$ & 109.3 & 21.3 & 72.6 & 4.6 & 59.7 \\
\hline$P_{5} \times P_{6}$ & 116.7 & 30.7 & 69.7 & 4.5 & 59.3 \\
\hline L.S.D at5\% & 3.50 & 2.64 & 4.41 & 0.58 & 9.88 \\
\hline
\end{tabular}

*, Significant at $5 \%$ level of probability. 
Table 4. Mean performance of parents and F2 for the studied characters.

\begin{tabular}{|c|c|c|c|c|c|c|}
\hline No. & Genotypes & $\begin{array}{l}\text { Plant } \\
\text { Height } \\
\text { (cm) }\end{array}$ & $\begin{array}{l}\text { No. } \\
\text { SP./PI. }\end{array}$ & $\begin{array}{c}\text { No. } \\
\text { K /SP }\end{array}$ & $\begin{array}{c}100 \\
\text { K.wt } \\
\text { (gm) }\end{array}$ & $\begin{array}{c}\text { G.Y } \\
\text { /PI } \\
\text { (gm) }\end{array}$ \\
\hline 1 & P1(Sids 1) & 108.0 & 20.6 & 71.0 & 4.1 & 65.3 \\
\hline 2 & P2(Giza 168) & 117.3 & 24.0 & 78.3 & 4.8 & 84.0 \\
\hline 3 & P3(Sakha 94) & 105.0 & 21.0 & 77.3 & 4.7 & 64.0 \\
\hline 4 & P4(Gem. 9) & 106.3 & 18.0 & 75.3 & 4.2 & 40.0 \\
\hline 5 & P5(Line 5) & 107.6 & 23.3 & 61.3 & 3.8 & 48.3 \\
\hline 6 & P6(Line 42) & 104.3 & 21.6 & 64.6 & 4.3 & 55.3 \\
\hline 7 & $P_{1} \times P_{2}$ & 90.3 & 21.3 & 64.0 & 4.7 & 54.3 \\
\hline 8 & $P_{1} \times P_{3}$ & 98.6 & 24.3 & 62.7 & 4.1 & 49.0 \\
\hline 9 & $\mathrm{P}_{1} \times \mathrm{P}_{4}$ & 93.3 & 20.3 & 56.3 & 3.6 & 38.0 \\
\hline 10 & $P_{1} \times P_{5}$ & 101.3 & 18.0 & 73.0 & 3.4 & 62.0 \\
\hline 11 & $P_{1} \times P_{6}$ & 105.3 & 24.4 & 54.7 & 3.5 & 61.0 \\
\hline 12 & $\mathrm{P}_{2} \times \mathrm{P}_{3}$ & 116.7 & 22.7 & 50.3 & 3.6 & 43.3 \\
\hline 13 & $\mathrm{P}_{2} \times \mathrm{P}_{4}$ & 104.7 & 25.3 & 74.7 & 4.3 & 57.7 \\
\hline 14 & $\mathrm{P}_{2} \times \mathrm{P}_{5}$ & 111.0 & 23.0 & 54.7 & 4.4 & 68.3 \\
\hline 15 & $\mathrm{P}_{2} \times \mathrm{P}_{6}$ & 107.7 & 17.0 & 51.7 & 4.0 & 62.3 \\
\hline 16 & $\mathrm{P}_{3} \times \mathrm{P}_{4}$ & 103.7 & 23.0 & 55.3 & 4.1 & 53.0 \\
\hline 17 & $P_{3} \times P_{5}$ & 102.3 & 21.7 & 61.0 & 3.7 & 48.3 \\
\hline 18 & $P_{3} \times P_{6}$ & 105.3 & 17.6 & 58.7 & 40 & 48.7 \\
\hline 19 & $\mathrm{P}_{4} \times \mathrm{P}_{5}$ & 102.3 & 19.0 & 55.3 & 4.0 & 43.0 \\
\hline 20 & $\mathrm{P}_{4} \times \mathrm{P}_{6}$ & 101.0 & 21.3 & 51.3 & 4.2 & 46.0 \\
\hline 21 & $P_{5} \times P_{6}$ & 102.7 & 19.0 & 51.0 & 4.3 & 45.0 \\
\hline \multicolumn{2}{|c|}{ L.S.D $\quad 5 \%$} & 5.85 & 3.04 & 6.26 & 0.479 & 8.62 \\
\hline
\end{tabular}

*, Significant at $5 \%$ level of probability.

\section{Inbreeding depression}

Estimates of inbreeding depression reported in Table (5) were in different directions (positive and negative), in all characters. This may be attributed to the dominance type of gene action controling these characters, especially in number of spikes/plant and number of kernels per spike. Results of Inbreeding depression in $\mathrm{F}_{2}$ generation for plant height showed that eight progenies gave positive depression ranged from $11.2-28.79$. For yield and its components most of these crosses showed 
postive inbreeding depression in 10,11,7 and 7 ranged from (13.41-39.29), (21.3159.33), (16-28-72.91) and (22.94-59.71)for number of spikes/plant, number of kernels per spike, 100- number of kernel weight and grain yield/plant, respectively. The data were in harmony with those obtained by several workers. Hamada and Tawfeleis (2003)

Table 5. Inbreeding depression $\%$ in $F_{2}$ for different characters

\begin{tabular}{|c|c|c|c|c|c|}
\hline Genotypes & $\begin{array}{l}\text { Plant } \\
\text { height }\end{array}$ & $\begin{array}{l}\text { No. } \\
\text { SP./PI. }\end{array}$ & $\begin{array}{c}\text { No. } \\
\text { K /SP }\end{array}$ & $\begin{array}{l}100 \\
\text { K.wt }\end{array}$ & $\begin{array}{l}\text { G.Y } \\
\text { /PI. }\end{array}$ \\
\hline $\mathrm{P}_{1} \times \mathrm{P}_{2}$ & $28.79 *$ & $13.41^{*}$ & $15.79 *$ & 4.26 & 15.16 \\
\hline$P_{1} \times P_{3}$ & $12.57 *$ & 1.62 & 14.53* & 4.65 & 27.19 \\
\hline $\mathrm{P}_{1} \times \mathrm{P}_{4}$ & $21.11^{*}$ & 6.45 & $17.82^{*}$ & $16.28 *$ & $38.41^{*}$ \\
\hline$P_{1} \times P_{5}$ & 5.40 & $18.18^{*}$ & $59.3 *$ & $22.72 *$ & 13.04 \\
\hline$P_{1} \times P_{6}$ & -1.48 & $12.86 *$ & -0.41 & $16.67 *$ & 23.11 \\
\hline $\mathrm{P}_{2} \times \mathrm{P}_{3}$ & 8.77 & 11.67 & $27.39 *$ & $29.41 *$ & $30.49 *$ \\
\hline $\mathrm{P}_{2} \times \mathrm{P}_{4}$ & $11.20^{*}$ & $26.87 *$ & $41.92 *$ & $72.91 *$ & 2963 \\
\hline$P_{2} \times P_{5}$ & 3.23 & 28.13* & 7.70 & 10.20 & $42.61^{*}$ \\
\hline$P_{2} \times P_{6}$ & $16.37 *$ & $39.29 *$ & 29.51* & 14.89 & $46.15 *$ \\
\hline $\mathrm{P}_{3} \times \mathrm{P}_{4}$ & -5.41 & -15.0 & $28.19 *$ & 8.88 & $33.42^{*}$ \\
\hline$P_{3} \times P_{5}$ & -5.72 & $19.63^{*}$ & 23.19* & 15.91 & 25.35 \\
\hline $\mathrm{P}_{3} \times \mathrm{P}_{6}$ & $11.91^{*}$ & $33.08^{*}$ & 31.13* & $18.37 *$ & $52.71^{*}$ \\
\hline $\mathrm{P}_{4} \times \mathrm{P}_{5}$ & 7.32 & $37.91 *$ & 21.31* & $18.37 *$ & $59.71 *$ \\
\hline $\mathrm{P}_{4} \times \mathrm{P}_{6}$ & 0.0 & 0.0 & 2.83 & 8.70 & 2.94 \\
\hline$P_{5} \times P_{6}$ & $11.99 *$ & $38.11^{*}$ & $26.82^{*}$ & 4.44 & 24.11 \\
\hline
\end{tabular}

Estimates of general combining ability effects for parents are presented in Table (6). High significant positive values would be of great interest in allstudied characters except for plant height where significant negative values would be more useful for the breeders point of view. Results indicated that the cultivar (Giza 168) $P_{2}$ is a good combiner for all studied characters while the (line 5) $P_{5}$ is the best combiner for plant height, number of spikes/plant and kernel weight and kernal weight . Moreover (line 42) $\mathrm{P}_{6}$ showed significant general combining ability effect for grain yield/plant

Specific combining ability was calculated for each cross and presented in Table (7). The crosses, $\left(P_{1} \times P_{2}\right),\left(P_{1} \times P_{3}\right),\left(P_{1} \times P_{4}\right),\left(P_{1} \times P_{5}\right),\left(P_{1} \times P_{6}\right)\left(P_{2} \times P_{5}\right),\left(3_{2} \times\right.$ $P_{4}$ )and $\left(P_{5} \times P_{6}\right)$ should significant specific combining ability effects for plant height. Also, crosses number 9,5 and 6 showed significant specific combining ability effects 
for number of spikes/plant, number of kernels/spike, kernel weight and grain yield/plant respitively. The $\operatorname{crosses}\left(\mathrm{P}_{2} \times \mathrm{P}_{5}\right),\left(\mathrm{P}_{4} \times \mathrm{P}_{5}\right)$ and $\left(\mathrm{P}_{3} \times \mathrm{P}_{6}\right)$ are considered promising for grain yield improvement as they sowed high specific combining ability effects. In such hybrids, desirable transgressive segregates would be expected in the subsequent generations.

Moreover GCA/SCA ratio was more than unity for plant height, number of kernels/spike and karnel weight, while, it was less than umtiy for number of spikes/plant and grain yield/plant proving that both additive and dominance genes, have considerable roles in the inheritance of these characters.

In concluion, cultivr Giza 168 is a good combiner for all studied characters while, line 5 is the best combiners for plant height, number of spikes/plant and kernel weight. Moreover, line 42 showed high general combining ability effect for grain yield/plant. These results may be useful to wheat breeders in making the proper decision for future crossing plans.

Table 6. Estimates of general combining ability (GCA), effects of wheat parants from $\mathrm{F}_{1}$ diallel crosses.

\begin{tabular}{|l|l|l|l|l|l|}
\hline S . of .v & Plant & No. & No. & 100- & G.Y \\
& height & SP./PI. & K /SP & K.wt & /PI. \\
\hline $\mathbf{F}_{\mathbf{1}}$ Hybrid & $-1.667^{*}$ & $-2.86^{*}$ & 0.375 & $-0.389^{*}$ & -7.014 \\
$\mathrm{P}_{1}$ & $3.833^{*}$ & $1.806^{*}$ & $3.375^{*}$ & $0.278^{*}$ & $10.611^{*}$ \\
$\mathrm{P}_{2}$ & $-2.083^{*}$ & $-0.444^{*}$ & 0.917 & -0.060 & -0.264 \\
$\mathrm{P}_{3}$ & 0.292 & 0.028 & 0.333 & -0.043 & $-5.264 *$ \\
$\mathrm{P}_{4}$ & $2.667^{*}$ & $1.264^{*}$ & -1.417 & $0.153^{*}$ & -0306 \\
$\mathrm{P}_{5}$ & $-3.042^{*}$ & -0.111 & $-3.583^{*}$ & 0.061 & $2.236 *$ \\
$\mathrm{P}_{6}$ & & & & & \\
L.S.D 5\% & 1.156 & 0.074 & 2.027 & 0.103 & 1.426 \\
Gi & 1.374 & 0.179 & 2.197 & 0.008 & 3.422 \\
Gi-Gj & & & & & \\
\hline
\end{tabular}

* Significant at $5 \%$ level of probability. 
Table 7. Estimates of specific combining ability (SC A effects for all the studied characters in the hybids.

\begin{tabular}{|c|c|c|c|c|c|}
\hline Genotypes & $\begin{array}{l}\text { Plant } \\
\text { height }\end{array}$ & $\begin{array}{l}\text { No. } \\
\text { SP./PI. }\end{array}$ & $\begin{array}{c}\text { No. } \\
\text { K /SP }\end{array}$ & $\begin{array}{r}100 \\
\text { K.wt }\end{array}$ & $\begin{array}{l}\text { G.Y } \\
\text { /PI. }\end{array}$ \\
\hline$P_{1} \times P_{2}$ & $1.643 *$ & -0.589 & -3.321 & $0.290 *$ & $-14.42 *$ \\
\hline$P_{1} \times P_{3}$ & $2.226 *$ & $1.661^{*}$ & -3.530 & 0.028 & -0.214 \\
\hline$P_{1} \times P_{4}$ & $1.851^{*}$ & -1.756 & 0.054 & 0.011 & -0.881 \\
\hline$P_{1} \times P_{5}$ & $1.476^{*}$ & -2.714 & $15.137 *$ & -0.018 & 3.827 \\
\hline$P_{1} \times P_{6}$ & $3.185^{*}$ & $4.661^{*}$ & 0.304 & 0.093 & 6.619 \\
\hline$P_{2} \times P_{3}$ & 0.726 & -1.631 & -4.530 & 0195 & $-22.83^{*}$ \\
\hline $\mathrm{P}_{2} \times \mathrm{P}_{4}$ & $-2.649 *$ & $6.619 *$ & 7.387* & $0.611^{*}$ & 1.82 \\
\hline$P_{2} \times P_{5}$ & 5. $976^{*}$ & 2.994* & $3.470 *$ & $-0.801^{*}$ & $34.20 *$ \\
\hline$P_{2} \times P_{6}$ & $-1.982 *$ & 0.369 & 2.304 & $-0.293 *$ & 27.99* \\
\hline $\mathrm{P}_{3} \times \mathrm{P}_{4}$ & $13.268 *$ & $3.536^{*}$ & $-4.155^{*}$ & -0.080 & $10.36^{*}$ \\
\hline$P_{3} \times P_{5}$ & $3.560 *$ & 0.577 & -3.071 & -0.380 & $9.58^{*}$ \\
\hline$P_{3} \times P_{6}$ & $-7.732 *$ & 0.619 & 7.429* & 0.245 & $46.20 *$ \\
\hline$P_{4} \times P_{5}$ & 0.185 & $3.494 *$ & 0.179 & 0.136 & $46.07 *$ \\
\hline $\mathrm{P}_{4} \times \mathrm{P}_{6}$ & -0.440 & $-4.798^{*}$ & -0.321 & $-0.720 *$ & -12.13 \\
\hline$P_{5} \times P_{6}$ & $4.518^{*}$ & 7.9118 & -0.905 & -0.435 & -17.42 \\
\hline L.S.D $\quad 5 \%$ & & & & & \\
\hline S ii & 0.801 & 0.383 & 1.065 & 0.018 & 7.332 \\
\hline Sij - Sik & 2.616 & 1.249 & 3.47 & 0.060 & 17.50 \\
\hline Sij-Skl & 2.243 & 1.071 & 2.98 & 0.512 & 15.2 \\
\hline
\end{tabular}

$*$, Significant at $5 \%$ level of probability. 


\section{REFERENCES}

1. Abd El-Hameed, A. S. 2002. Analysis of variance and its components of some hexaploid wheat crosses. M.Sc. Thesis. Agron. Dep., Fac. Agric., Minia Univ. Egypt.

2. Ashoush, H. A., A. A. Hamada and I. H. Darwish. 2001. Heterosis and combining ability in $F_{1}$ and $F_{2}$ diallel crosses of wheat (Triticum aestivum/.) J. Agric. Sci. Mansoura Univ., 26 (5):2579-2592.

3. Dawam, H. A. and F. A. Hendawy. 1990. Inheritance of yield and its components in common wheat (Triticum aestivum L.). Proc. $4^{\text {th }}$ Agron. Conf. Cairo, 15-16 Seot., 1990.

4. Darwish, I. H. 1992. Breeding studies on wheat. M.Sc. Thesis., Fac. Of Agric., Menumberfia Univ., Egypt.

5. Edwards, L. H., H. Ketata and L. L. Smith. 1976. Gene action of heading date, plant height and other characters in two winter wheat crosses. Crop Sci. 16: 275277.

6. El-Hennawy, M. A. 1992. Inheritance of grain yield and other agronomic characters in two wheat crosses. Al-Azhar J. Agric. Res. 15: 57-68.

7. El-Sayed, E. A. M., A. M. Tamam and S. A. Ali. 2000. Genetical studies on some bread wheat crosses ( Triticum aestivum L.), Menufiya J. Agric. Res., 25 (2): 389401.

8. Griffing, B. 1956. Concept of general and specific combining ability in relation to diallel cross systems. Aust. J. Biol. Sci., 9: 463-493.

9. Hamada, A. A. and M. B. Tawfeleis. 2003. Genetic and graphical analysis of diallel crosses of some bread wheat (Triticum aestivum), J. Agric. Res. Tanta Univ., 27 (4): 633-647.

10. Hendawy, H. I. 1990. Breeding for yield and its components in wheat. M.Sc. Thesis, Fac. Agric., Menufia Univ., Egypt.

11. Ikram, U.H. and L. Tanah. 1991. Diallel analysis of grain yield and other agronomic traits in durum wheat. Rachis 10: 13.

12. Mekhamer, K. I. S. 1995. Breeding for some quantitative traits in common wheat. M.Sc. Thesis, Fac. Of Agric., Menumberfia Univ., Egypt.

13. Mohammed, K. A. H. 1999. Genetic studies on some yield traits of durum wheat. M.Sc. Thesis, Fac. Of Agric., Assuit Univ., Egypt. 
14. Mostafa, A. K. 2002. Diallel crosses analysis for yield and yield components in wheat. J. Agric. Sci Mansoura Univ., 27 (12): 8051-8060

15. Salem, A. H. and E. E. Hassan. 1991. Estimates of some breeding parameters for

16. yield and its attributes in wheat line $x$ tester analysis. Zagazig J. Agric. Res., 18

17. (5): $1357-1368$.

18. Sharma, R. C. and E. L. Smith. 1986. Selection for high and low harvest index in three winter wheat populations. Crop Sci., 26: 1147-1150.

19. Steel, R. G. D. and J. H. Torri. 1980. Principles and Procedures of Statistical Biometrical Approaches. $2^{\text {nd }}$ McGraw-Hill Book Company, New York, London.

20. Uddin, M. M. and O. I. Joarder. 1987. Genetic architecture of heading date, fertile ear number and yield of wheat. Pak. J. Agric. Res., 7: 1-9. 


\section{تحليل بعض هجن قمح الدائرية للمحصول ومكوناته}

\section{وفاء عبل الحميد العوضى عباح حزة ابو العلا}

$$
\text { قسم بحوث القهح - معهد بحوث المحاصيل الحقلية - مركز البحوث الزراعية }
$$

أجرى تقيمية الهجن الدائرية فى اتجاه واحد لستنة تز اكيب ور اثية من قمح الخبز (صنف سدس 1 ) و (الصنف جيزة 168) و (الصنف جمبزة 9) و (الصنف سخا 94) و (السلالة 5) و (السلالة 42) بمحطة البحوث الزر اعية بهنيم لنقدير القدرة العامة و الخاصة على الائتلاف فى الجيل الأول و التعرف على العو امل الور اثية التى تتحكم فى صفة المحصول ومكوناته ويمكن تلخيص النتائج

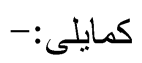
وذللك لتقدير القدرة العامة والخاصة على الائتلاف فى الجيل الاول وتاثير التزبية الداخلية و التعرف على العو امل الور اثية التى تتحكم فى المحصول ويمكن تلخيص النتائج كالاتى:

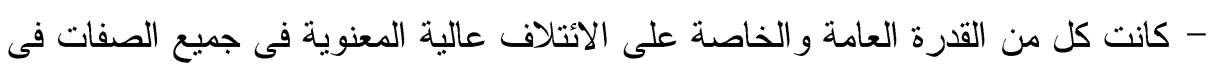

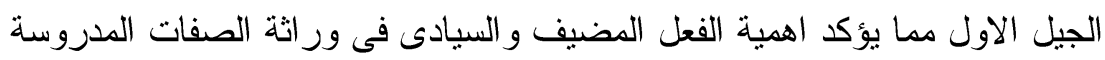

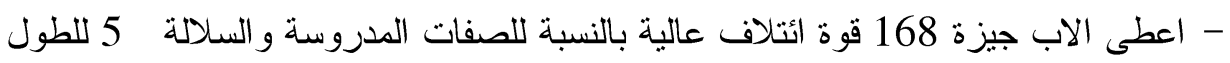
و عدد السنابل ووزن الحبوب و السلالة 42 للمحصول ويمكن استخدام هذه الأباء فى برنامج

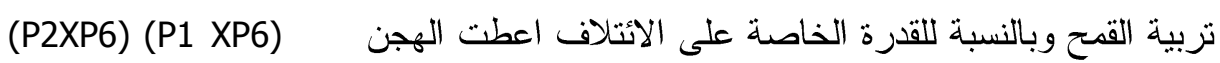
(P2XP3)

- اظهرت النتائج وجود تاثير للتربة الداخلية فى ثلاث تر اكيب ور اثية ذات معنوية عالية لصفة محصول النبات مما يدل على إمكانية الاستفادة من هذه الهجن فى الحصول على قوت تئرة الهجين فى - قياس القدرة العامة على الايتّلاف كانت اكبر من قياس القدرة الخاصة على الائتلاف فى في بعض الصفات مما يدل على اهمية الفعل الجينى المضيف فى نو ارث هذه الصفات. 